\title{
Work Attitudes Among Office Personnel at MSU-lligan Institute of Technology, lligan City Philippines
}

\author{
Katrina L. Codilla ${ }^{1}$, Jalil E. Quinal ${ }^{2}$ \\ ${ }^{1}$ Guidance and Counseling Center, Mindanao State University-Iligan Institute of Technology, Iligan City, \\ Philippines \\ ${ }^{2}$ Xavier University-Ateneo de Cagayan, Cagayan de Oro, Philippines \\ 1atrina.codilla@g.msuiit.edu.ph; ${ }^{2}$ jequinal@gmail.com \\ DOI: https://doi.org/10.18196/jgpp.61105
}

Article Info

Article history:

Received 22 Okt 2018

Revised 01 Jan 2019

Accepted 15Jan 2019

Key Words:

work attitude; status

of employment,

generation;

educational

achievement.

\begin{abstract}
The skills, competencies, and attitudes of employees determine the success or failure of any organization. The attainment of the objectives of an organization is determined in terms of profit or advancement of status. Thus, when employees do not perform well, the productivity of the organization suffers.

This is a correlation study which explores the work attitude of employees using the variables such as generation, length of service, academic achievement, and employment status. A work attitude questionnaire $(\alpha=0.856)$ composed of statements relating to the manifestation and consideration of attitudes, habits, and behaviors was utilized. A total of 147 participants were determined using the purposive-convenient sampling procedure.

Major findings include that female millennials as the foremost office personnel in the Institute. Majority are permanent employees with college degrees and have been working for more than ten years. The work attitude of the participants was excellent for Generation X participants, Master's degree holder, employed as casuals, and those who have been working for more than five years. There is a significant relationship which was found between the participants' work attitude and the variables generation, academic achievement, length of service, and status of employment.

With these findings, it is then deduced that the work attitude of the employees is affected with their status of employment, generation, academic achievement, and length of service. Thus it is recommended that office personnel must pursue higher education and the management should provide avenue for their scholastic development. It is also recommended that further studies be undertaken to explore work attitudes alongside the performance of the participants such as punctuality and output.
\end{abstract}

\section{INTRODUCTION}

The skills, competencies, and attitudes of employees determine the success or failure of any organization (Angeles \& Llanto, 2014). The attainment of the objectives of the organization is determined in terms of profit or advancement in status (Mayhew, n.d). Thus, when employees do not perform well, the productivity of the organization suffers. Julie Boehlke (2015) stated that good work attitude determines 
16 the productivity of the office. This is supported by Singh (2014) who found a relationship between work attitude and behavior across generations.

Work attitude, in terms of job satisfaction and organizational commitment, has been found to have a significant effect on employee outcomes - performance, tardiness, absenteeism, turn-over, and working environment (Harrison et al, 2006; Garner and Hunter, 2011). Attitudes and values can vary depending on the environment, roles of an employee, and may also be a result of age and length of tenure (Chiu, Chang, and Wei. 2016; Gibson \& Klein, n.d.)

Attitudes are the map of the employees that allow them to adjust, navigate, and behave appropriately to their environment and various situations (Angeles \& Llanto, 2014). Studies exploring the effects of various variables towards employee behavior and attitude involved generation gap, marital status, and gender among others. There is a limited study on the effect of status of appointment and educational attainment toward employee outcomes. Accordingly, one of the major issues in the Philippine industry is that most employees are hired as "permanent casuals" (Handbook for APL Activist, n.d.). Using Maslow's Hierarchy of Needs, security, or in the case of employees, job security is an important factor for each person (Feist \& Feist, 2009). Maslow further argued that employee concerns need to be studied for the management to create and implement policies which will satisfy the upper levels of Hierarchy of Needs (Ewen, 2010).

Thus, this study aims to describe the work attitude among the office personnel of MSU-Iligan Institute of Technology, Iligan City. Specifically, this is an attempt to find answers to the following research objectives:

(1) Profile the participants in terms of generation, educational attainment, status of appointment, and length of service;

(2) Level of work attitude of the participants;

(3) Test the significant difference of the work attitude of the participants in terms of generation, educational attainment, status of appointment, and length of service; and 
(4) Test whether there is correlation of the variables generation, educational attainment, status of appointment, and length of service on the work attitude of the participants.

The results of this study will be significant to schools, office personnel, and human resource management offices (HRMO). Schools, as training ground of the students for their employment, will be able to prepare the students and increase their employability. On the other hand, office personnel will be enlightened on what factors are best improved in order to perform well at work. Also, the management will be made aware on what programs should be developed and implemented for the holistic development of the organization's constituents.

\section{LITERATURE REVIEW}

\section{Generation in the Work Place}

There are three primary generations now in the workforce, possessing unique characteristics affecting work ethic and relationship (Glass, 2007). Several studies infer that those belonging to Generation X and 'Millennials' value leisure more, see work as less central to their lives and display a weaker work ethic compared to the older generations (Twenge \& Psychol, 2010). This is along the lines of the findings of Cennamo and Gardner (2008) showing the younger generations place more importance on status and freedom as their work values compared to the older groups. However, the study of Wong et al (2008) does not uphold commonly attributed stereotypes among generations. The observed differences are attributing more with age rather than generation.

In the Philippines, Filipino workers in their mid-twenties and mid-fifties are found to be more alike than different. Both believe that work should provide personal growth, desire for development, contribution and cooperation. Younger workers however show marked preference for greater participation and empowerment in the workplace compared to older employees (Claudio-Pascua, 2005).

\section{Employment Status and Tenure}

In the Philippines, there are several types of employment status in the government - job order, casual, temporary and permanent. Job order, or individual 
contract of services, refers to a type of employment where there is no employeremployee relationship between the individual and the government (Resolution No. 020790, 2002). Thus, the individual is paid on daily basis and does not enjoy benefits such as bonuses, Personal Economic Relief Allowance (PERA), Representation and Transportation Allowance (RATA), and leave benefits among others. Casual and permanent employments enjoy similar benefits except for security of tenure. Unlike permanent government employees, casual employees can be dismissed any time (Macaraya, n.d.).

Permanent employees have higher organizational commitment and job satisfaction than part time workers when they work a preferred schedule but lower than part time workers when working an un-preferred schedule. Results however partially supported only the hypothesis for full time workers, but fully support the hypothesis for part-time workers (Lee and Johnson, 1990).

Scholars are also concerned about the status of contingent employees. They hypothesized that temporary workers experience more adverse psychological job outcomes compared to permanent employees. Temporary employees report higher psychological well-being and life satisfaction after controlling for differences in satisfaction and security. Contracts with definite duration can lower individual wellbeing because of heightened job insecurity. Job insecurity can lead to serious negative consequence to job attitudes, organizational attitude, health, and to a point, their behavioral relationship in the organization (Dawson et al, 2014 and Sverke et al, 2002). Longer tenure improves employee work contribution while short-tenured employees have high turnover intention and less work contribution (Bal, Cooman, \& Mol, 2013).

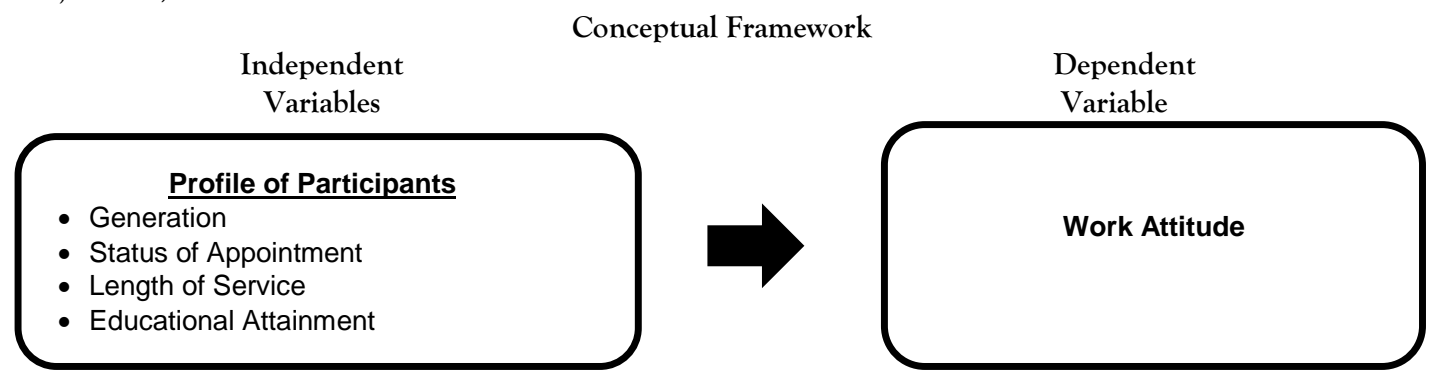

Fig.1. Schematic Diagram showing the relationship between the independent variables and the dependent variable

Figure 1 shows the independent and dependent variables of the study. The profile of the participants is the independent variable while work attitude is the dependent variable. 
Abraham Maslow postulated that humans are driven by two motives - deficiency motive and growth motive. Deficiency motives (D-motives) are possessed by all and aim to reduce drives such as hunger, thirst, safety. This motive may be satisfied by people or objects. On the other hand, Growth motives (B-motives) are independent and unique to each person. The aim of this motive is to increase pleasurable drives. Therefore, D-motives drive self-preservation and B-motives pushes for a better level of functioning (Ewen, 2010).

Using these motives as basis, Maslow theorized that each person needs to satisfy various levels of needs in order to reach transcendence. These levels are physiological, safety, social, esteem, and self-actualization respectively. Each level of need has to be satisfied to a certain degree for a person to progress (Feist \& Feist, 2009).

For this study, generation, status of appointment, length of service, and educational attainment have relationships with the work attitude of employees. Each generation has their own set of beliefs and experiences which may cause distinctiveness of attitude towards work. Compensation and benefits, which include educational progress, of employees can also affect the perception and behavior of employees towards their work and organization. The length of employment may also affect how employees respond to their organization and responsibilities. Thus, the following null hypotheses are forwarded:

$\mathrm{H}_{01}$ : There is no significant difference of work attitude of the participants in terms of generation, educational attainment, status of appointment, and length of service.

$\mathrm{H}_{02}$ : There is no correlation of the variables generation, educational attainment, status of appointment, and length of service on the work attitude of the participants.

\section{METHOD}

This section of the paper presents the research design, participants, locale of the study, materials used and data analysis method.

\section{Research Design}


This paper is a quantitative research which utilized structured questionnaire in gathering the data.

\section{Participants}

There are a total of 147 participants of this research, of which 52 are males and 95 are females. They are MSU-Iligan Institute of Technology office personnel who are currently employed by the Institution. These personnel are stationed at the different administrative offices, colleges, and technical offices around the campus. In determining the sample, this study utilized purposive-convenient sampling. The following criteria were used in deciding who would be included in the sample: 1) an office employee of MSU-IIT; 2) permanent or appointed as casual or job order; and 3) available during the time of data gathering.

\section{Locale of the Study}

This research was undertaken in Mindanao State University-Iligan Institute of Technology (MSU-IIT) which is an autonomous unit of the Mindanao State University (MSU) System located at Iligan City, Philippines. The Institute hosts 6 colleges and 3 schools with several departments and 51 offices. There are 116 lecturers, 490 faculty members, and 413 office personnel. Of these office personnel, 288 are permanent, 125 are casual, and 73 are job order (MSU-Iligan Institute of Technology, 2014).

\section{Materials}

This investigation utilized a structured questionnaire composed of two parts. Part 1 covers the profile of the participants. Part 2 is the work attitude questionnaire $(\alpha=.856)$ which is composed of statements relating to the manifestation and consideration of attitudes, habits, and behaviors. The participants were asked to rate their degree of feeling or evaluation with the statements presented in a scale of 1 to 10 where ten (10) is the highest and one (1) the lowest. 


\section{Data Analysis}

Two statistical tools were used in this research. Descriptive statistics, like frequency count and percentage distribution were used in analyzing the data on the profile. Then in analyzing the data on work attitude, mean was used. In determining whether significant differences among the variables on work attitudes exist, KruskalWallis H Test was used. Kruskal-Wallis H Test, or the one-way ANOVA on ranks, is a rank-based non-parametric test that is used to test for statistical difference between two or more groups of independent variables (Laerd Statistics, n.d.). Also, in testing for relationships, Kendall Rank Correlation (Kendall's Tau-b) was used. It is a nonparametric test that measures the strength of dependence between variables (Statistics Solutions, 2017).

The means of the level of work attitude are described as follows: Excellent (9.0110.00), Good (8.01-9.00), Average (6.01-8.00), and Poor (1.00-6.00).

\section{RESULTS}

\section{Profile of the participants.}

Generation. Of the total participants, 50\% of them are millennial, $29 \%$ are Baby Boomer, are $22 \%$ are Generation X.

Educational Attainment. Data revealed that $81 \%$ are college degree holder, $16 \%$ finished Master's degrees, and 3\% are vocational graduates.

Status of Appointment. It is revealed that $47 \%$ of the participants have a permanent job status, while $32 \%$ have casual status, and $21 \%$ are job order status.

Length of Service. Findings show that $41 \%$ of the participants have been working in the Institute for more than 10 years followed by $36 \%$ of them who have been working for 1-5 years, and then followed by those working between 5-10 years. Lastly $10 \%$ of the participants have been working for less than a year. 


\section{Level of Work Attitude}

Table 1. Level of Work Attitude

\begin{tabular}{|l|l|c|l|}
\hline \multicolumn{1}{|c|}{ Variable } & \multicolumn{1}{|c|}{ Category } & $\begin{array}{c}\text { WA } \\
\text { Mean }\end{array}$ & \multicolumn{1}{|c|}{ Interpretation } \\
\hline \multirow{4}{*}{ Generation } & Baby Boomer & 8.91 & Good \\
\cline { 2 - 4 } & Generation X & 9.30 & Excellent \\
\cline { 2 - 4 } & Millennial & 8.87 & Good \\
\hline \multirow{4}{*}{ Sducational Attainment } & Vocational & 8.09 & Good \\
\cline { 2 - 4 } & College & 8.89 & Good \\
\cline { 2 - 4 } & Master's Degree & 9.34 & Excellent \\
\hline \multirow{5}{*}{ Length of Service } & Job Order & 8.67 & Good \\
\cline { 2 - 4 } & Casual & 9.10 & Excellent \\
\cline { 2 - 4 } & Permanent & 8.98 & Good \\
\cline { 2 - 5 } & Less than 1 year & 8.66 & Good \\
\cline { 2 - 4 } & 1-5 years & 8.97 & Good \\
\cline { 2 - 4 } & 5-10 years & 9.12 & Excellent \\
\cline { 2 - 4 } & More than 10 years & 9.04 & Excellent \\
\hline
\end{tabular}

Table 1 presents the work attitude of the participants in terms of generation, educational attainment, status of appointment, and length of service. In terms of generation, it is revealed that Generation X have "excellent" work attitudes (9.30) while Baby Boomers and Millennial only have "good" work attitude (8.91 \& 8.87) respectively. Next, in terms of educational attainment, master's degree holders have "excellent" work attitude (9.34) while college and vocational graduates only have “good" work attitudes (8.89 \& 8.09).

In terms of status of appointment, casual participants reported "excellent" work attitudes (9.10) while permanent and job order participants reported "good" work attitude (8.98 \& 8.67). Lastly, in terms of length of service, participants who have been working for $5-10$ or more than 10 years have "excellent" work attitudes $(9.12 \&$ 9.04) while participants who have been working for less than 1 year to five years only have "good" work attitude (8.66 \& 8.97).

This study supports the results of Singh (2014) and Park \& Gursory (n.d.) where Generation X employees have higher attitude towards their work. The difference in work attitude could be attributed to dissimilarity in life experiences - environment, technology, and society - that each generation encountered (Schroer, n.d.). Identified 
qualities of Generation X are practical, independent, successful, and hard workers (Mann, 2006). Comparably, Millennial office personnel may have lower work attitude because of their identified characteristics of being idealistic, having short attention span, values personal time more, highly selective, and segmented in terms of group cohesiveness (Halroyd, 2011; Schroer, n.d.; Mann, 2006).

\section{Differences on Work Attitude}

The Analysis of Variance in terms of the different profile categories, tested at 0.05 level of significance, revealed significant differences in work attitude.

The generation category has an h-value of 13.0167 tested against 7.815 which means that there is significant difference in work attitude among participants who were born during 1945-1964 (Baby Boomers), 1961-1979 (Generation X), 1980-1995 (Millennial). Next, the length of service has an h-value of 11.5163 tested against 9.488 which means that there is significant difference among the participants who have been working for less than a year, between $1-5$ years, between $6-10$ years, and more than 10 years.

Subsequently, educational attainment has an h-value of 9.6416 tested against 5.991 which means that there is significant difference among the participants who finished vocational courses, college, and masters. Lastly, status of appointment has an h-value of 11.7969 tested against 5.991 which means that there is significant difference among the participants who are permanent, casual, and job order.

In summary, data reveal that generation, status of appointment, educational attainment, and length of service affect the work attitude of the office personnel of the Institute.

Relationship of the Profile and Work Attitude

Table 2. Kendall's Tau-b Correlation

\begin{tabular}{|l|c|c|c|c|}
\hline \multirow{2}{*}{$\begin{array}{c}\text { Profile of the } \\
\text { Participants }\end{array}$} & $\mathbf{4}$ & Correlation Coefficient & Sig. (2-tailed) & Interpretation \\
\cline { 2 - 5 } & 135 & $-.157^{*}$ & .023 & significant \\
\hline Generation & 145 & $.149^{*}$ & .025 & significant \\
\hline Status of Appointment & 143 & $.197^{* *}$ & .005 & significant \\
\hline Educational Attainment & 110 & $.171^{*}$ & .023 & significant \\
\hline Length of Service & *. Correlation is significant at the 0.05 level (2-tailed). \\
& **. Correlation is significant at the 0.01 level (2-tailed).
\end{tabular}


Table 2 presents the relationship of the variables which are generation, status of appointment, educational attainment, and length of service. Results show that educational attainment has the strongest positive significant relationship with work attitude (.197) test at 0.01 level of significance. This implies that higher level of education results to better work attitude. Next status of appointment and length of services have positive significant relationship with work attitude $(.149 \& .197)$ at 0.05 level of significance. This implies that better status of appointment and longer years of service results to better work attitude. Lastly, generation is shown to have a significant negative correlation with work attitude (-.157). This indicates that the younger participants have lower work attitude.

\section{DISCUSSION AND IMPLICATION}

The results highlight the importance of obtaining higher degree of education. This line of thinking coincides with the study of Liang et. al. (2013) in which they found that education and training have positive influence on the work attitude of employees (Liang, et. al., 2013). Accordingly, higher education allows better and indepth knowledge of the field and allows development of skills such as problem-solving, critical reasoning, and innovation (Tzanakou, 2014).

The status of appointment of employees is shown to be a factor on how employees approach their work. It is interesting to note, however, that casual employees have the highest work attitude. While, permanent and job order employees rated their work attitude as good only. It was discussed in the previous chapters that job security plays a vital role in the job satisfaction of employees which subsequently affects work attitude and behavior (Dawson et al, 2014; Wilkin, 2012; Sverke et. al., 2002). The findings for this study only partially support this notion. Casual and permanent employees enjoy similar benefits except for the job security. Perhaps this security makes the permanent employees complacent on their work attitude. Accordingly, several articles and researches have highlighted how security of tenure had made teachers and other professionals uncaring and unworried on work evaluation which has been affecting their performance (Anthony Baghdady, 2015, March 9; Asbill et. Al., 2016; Guillebeau, n.d.) 
Lastly, the comparison on the lengths of service shows that the longer an employee works for the organization, the better their work attitude. Office personnel working for five to ten years or more rated their work attitude as excellent. This result relates to the findings of Bal et. al. (2013) where employees who worked longer have reported to contribute more to their organization whereas employees who are relatively new gives less contribution and expresses higher possibility of leaving. However, for this study, it should be noted that office personnel working for five to ten years have the highest rating for their work attitude. Nevertheless, the result coincides with Hur \& Perry (2014) where they found that moderate tenure has the strongest work attitude while longer and shorter tenures yielded weak work attitudes. Similar conclusions were made by Wright \& Bonett (2002).

\section{CONCLUSION}

The work attitude of MSU-IIT office personnel are affected by factors such as generation, educational attainment, length of service, and status of appointment. The importance of pursuing higher studies such as master's degrees is beneficial to both the office personnel and organization as it increases the skills of the workers. With more knowledge and skills, employees are better equipped to do their tasks, assist others, and improve the efficiency in the workplace. Moreover, better compensation and benefits motivate office employees to perform however, when their tenure is secured, they become complacent. It is therefore recommended that office personnel to pursue advance studies and attain higher education to improve and develop their skills. For the management, it is recommended that they provide avenue, such as scholarships and grants, to office personnel to pursue higher education. As well as improve the status of appointment of job order personnel, and, develop programs to reduce complacency and motivate permanent employees.

However, some limitations of this study need to be acknowledged. First, work attitude measured in this study refers to the subjective evaluation of participants towards the different aspects related to work. Also the study only explored the direct relationship of the variables such as generation, tenure, status of appointment, and academic achievement to work. attitudes. Lastly, participants are from an academic 
institution supported by the government Thus conclusions are limited to data gathered. Thus, it is recommended to explore work attitudes alongside the performance (e.g. productivity, absenteeism, tardiness) of the participants in the office, as well as, to investigate the variables used in this study in qualitative terms to obtain in-depth understanding. Lastly, it is recommended to conduct a similar study but to office personnel from different private and public institutions and agencies.

\section{REFERENCES}

Alliance of Progressive Labor (n.d). Handbook of APL Activists-Primer. Retrieved from http://www.apl.org.ph/?page_id= 1575

Angeles, A.L.P. \& Llanto, G.M.N. (2014). Chapter Productive work behaviors and attitudes. In Hechanova et al. (Ed.), Understanding the Filipino Worker and Organization (pp. 95106). Quezon City, Philippines: Ateneo de Manila University

Asbil, S., Moultry, A.M., Policastri, A., Sincak, C.A., Smith, L.S., Ulbrich, T.R. (2016). Debating the Effectiveness and Necessity of Tenure in Pharmacy Education. Am J Pharm Educ. 2016 Aug 25; 80(6): 94. doi: 10.5688/ajpe80694

Baghdady, A. (2015, March 9). Tenure fosters complacency, shortchanging students of a quality education (in opinion). Retrieved from https://dailytitan.com/2015/03/tenurefosters-complacency-shortchanging-students-of-a-quality-education/

Bal, P.M, de Cooman, R, \& M ol, S.T. (2013). Dynamics of psychological contracts with work engagement and turnover intention: The influence of organizational tenure. European Journal of Work and Organizational Psychology, 22(1), 107-122. doi:10.1080/1359432X.2011.626198

Boehlke J. (2015), Importance of Good Attitude at Work. Retrieved from http://www.livestrong.com/article/180053-importance-of-good-attitude-at-work/

Cennamo L. and Gardner D. (2008) Generational Differences in Work Values, Outcomes, and person-organization values fit. Journal of Managerial Psychology, Vol. 23 Iss: 8, pp.891 - 906. Retrieved from

https://www.researchgate.net/publication/235297699_Generational_Differences_in_W ork_Values_Outcomes_and_Person-Organization_Values_Fit

Chiu C, Chang H, Wei C (2016) Person-Organization Fit and the Attitude of Medical Staff: Professionalism and Work Attitude in a Chinese Hospital. doi:10.4172/23157844.1000191. Retrieved from http://www.omicsonline.com/openaccess/personorganization-fit-and-the-attitude-of-medical-staff-professionalismandw ork-attitude-in-a-chinese-hospital-2315-7844-1000191. php?aid = 77224

Cohen, A. (1993). Age and Tenure in Relation to Organizational Commitment: A MetaAnalysis. DOI: 10.1207/s15324834basp1402_2

Crawford, J., Leonard, L.N.K., \& Jones, K. (2013). The role of worker tenure and employment heterogeneity on software development work activities. JISTEM Journal of Information Systems and Technology Management, vol. 10, no.3 São Paulo Dec. 2013. http://dx.doi.org/10.4301/S1807-17752013000300002 
Dangla, D. (2014, November 10). GM A 7 talents fight against unfair labor practice. Manila Today. Retrieved from http://www.manilatoday.net/gma-7-talents-fightagainst-unfair-labor-practice/

Dawson D. (2014) Temporary employment, job satisfaction and subjective well-being. Economic and Industrial Democracy. Retrieved from http://eid.sagepub.com/content/early/2014/12/16/0143831X14559781.abstract

Ewen, R.B. (2014) Abraham H. M aslow Self-Actualization Theory (II). An Introduction to Theories of Personality $7^{\text {th }}$ ed. pp.203-220. New York, NY: Psychology Press $\&$ Taylor Francis Group

Feist, J, \& Feist, G.J. (2009) Maslow: Holistic-Dynamic Theory. Theories of Personality $7^{\text {th }}$ ed. international edition. pp274-307. New York, NY: McGraw-Hill Education (Asia).

Garner B.R. and Hunter B.D. (2013) Examining the temporal relationship between psychological climate, work attitude, and staff turn-over", Journal of Substance Abuse Treatment, Volume 44, Issue 2, February 2013, pp. 193-200. Retrieved from http://www.sciencedirect.com/science/article/pii/S0740547212000840

Gelene (2015, August 5). The Ordeal of Job Orders in the Government. Retrieved from http://thepinoycivilservant.com/2015/08/05/the-ordeal-of-job-orders-in-thegovernment/

Gibson J.L. and Klein S.M . (n.d) Employee Attitudes as a Function of Age and Length of Service: A Reconceptualization. Retrieved from http://amj.aom.org/content/13/4/411.short

Glass A. (2007) Understanding generational differences for competitive success. Industrial and Commercial Training, Vol. 39 Iss: 2 pp. 98-Retrieved from http://www.emeraldinsight.com/doi/abs/10.1108/00197850710732424

Guillebeau, C. (n.d.) The Link Between Security and Complacency [Article]. Retrieved from https://chrisguillebeau.com/the-link-between-security-and-complacency/

Harrison D.A., Newman D.A., and Roth P.L. (2006) How Important are Job Attitudes? Meta-Analytic Comparisons of Integrative Behavioral Outcomes and Time Sequence. Retrieved from http://amj.aom.org/content/49/2/305

Hur, H. \& Perry, J.L. (2014). The Relationship Between Job Security and Work Attitudes: A M eta-Analysis Examining Competing Theoretical M odels [Abstract]. Retrieved from https://papers.ssrn.com/sol3/papers.cfm?abstra ct_id $=2452082$

Laerd Statistics, (n.d) Kruskall-Wallis H-test using SPSS statistics. Retrieved from https://statistics.laerd.com/spss-tutorials/kruskal-wallis-h-test-using-spss-statistics.php

Lee T.W. and Johnson D.R. (1990) The Effects of Work Schedule and Employment Status on the Organizational Commitment and Job Satisfaction of Full versus part time employees. Journal of Vocational Behavior, Volume 38, Issue 2, April 1991, Pages 208224. Retrieved from http://www.sciencedirect.com/science/article/pii/000187919190028K

Liang, H.M et. al. (2013). The Influence of Education and Training on Work Attitudes and the Moderating Effect of Supervisor Attitudes: Examining Chinese Employees [Abstract]. Retrieved from http://link.springer.com/article/10.1007/s11205-013-0505-6

Macaraya, B.M. (n.d.). The Philippines: Workers' Protection in a New Employment Relationship. Retrieved from http://www.ilo.org/wcmsp5/groups/public/--ed_dialogue/---dialogue/documents/genericdocument/wcms_2 05376.pdf 
Mayhew R. (n.d) Importance of Employee Performance in Business Organizations. Retrieved from http://smallbusiness.chron.com/importance-employee-performance-businessorganizations-1967.html

Park, J., \& D. Gursoy. (2012). Generational Effects on Work Engagement among U.S Hotel Employees [Abstract]. International Journal of Hospitality Management 31 (4): 11951202. https://doi.org/10.1016/j.ijhm.2012.02.007

Philippine Labor Laws. (2008). Retrieved from http://www.laborlaw.usclaw.org/2010/11/29/security-of-tenure/

Resolution No. 020790. (2002). Retrieved from http://www.csc.gov.ph/phocadownload/useruplo ad/itduser/res-020790.html.pdf

Schroer W.J. (n.d.) "Generations $X, Y, Z$ and the others". Retrieved from http://so cialmarketing.org/archives/generations-xy-z-and-the-others/

Singh, V. (2014). Does Work Attitude result into Work Behavior for older and younger generation? aWEshkar Vol. XVII Issue 1 March 2014 WeSchool. Retrieved from http://www.welingkar.org/Corporates/pdfs/aWEshkar/march2014/aWEshkar_10_Resear chNote_ViabhavSingh.pdf

Statistics Solutions. (2017). Correlation (Pearson, Kendall, Spearman). Retrieved from http://www.statisticssolutions.com/correlation-pearson-kendall-spearman/

Sverke M., Hellgren J., Näswall K. (2002) No security: A meta-analysis and review of job insecurity and its consequences. Journal of Occupational Health Psychology, Vol 7 (3), July 2002, 242-264. Retrieved from http://psycnet. apa.org/index.cfm?fa = search.displayRecord\&uid=2002-01632-005

Twenge J.M. (2010) A review of The Empirical Evidence on Generational Differences in Work Attitudes. Journal of Business Psychology 25:201. Retrieved from http://link.springer.com/article/10.1007/s10869-010-9165-6

Tzanakou, C. (2014, April 11). The wider benefits of a PhD. University World News. Retrieved from http://www .universityworldnews. com/article.php? story=20140409095727966

Wilkin, C.L. (2012) I can't get no job satisfaction: Meta-analysis comparing permanent and contingent workers. Journal of Organizational Behavior, Volume 34, Issue 1, January 2013 Pages 47-64. Retrieved from http://onlinelibrary.wiley.com/doi/10.1002/job.1790/full

Wright, TA, \& Bonett, DG. (2002) The moderating effects of employee tenure on the relation between organizational commitment and job performance: A meta-analysis. [Abstract]. Journal of Applied Psychology, Vol 87(6), Dec 2002, 1183-1190. http://dx.doi.org/10.1037/0021-9010.87.6.1183

Wong M., Gardiner E., Lang W., and Coulon L. (2008) Generational Differences in Personality and Work Values: Do they exist and what are the implications for the workplace? Journal of Managerial Psychology, Volume 23, Number 8, 2008, pp. 878890 (13). Retrieved from http://www.ingentaconnect.com/content/mcb/05 0/2008/00000023/00000008/art00003 